\title{
Factors associated with normal and cesarean delivery in public and private maternity hospitals: a cross-sectional study
}

\author{
Fatores associados ao parto normal e cesárea em maternidades públicas e privadas: estudo transversal \\ Factores asociados con el parto normal y por cesárea en hospitales de maternidad \\ públicos y privados: un estudio transversal
}

Thales Philipe Rodrigues da Silva' ORCID: 0000-0002-7115-0925

Erica Dumont-Pena' ORCID: 0000-0003-1220-6041

Alexandra Dias Moreira' ORCID: 0000-0002-4477-5241

Bárbara Araujo Camargos' ORCID: 0000-0002-2478-8002

Marivania Queiroz Meireles' ORCID: 0000-0003-3493-2538

Kleyde Ventura de Souza' ORCID: 0000-0002-0971-1701

Fernanda Penido Matozinhos' ORCID: 0000-0003-1368-4248

'Universidade Federal de Minas Gerais. Belo Horizonte, Minas Gerais, Brazil.

How to cite this article: Silva TPR, Dumont-Pena E, Moreira AD, Camargos BA, Meireles MQ, Souza KV, et al. Factors associated with normal and cesarean delivery in public and private maternity hospitals: a cross-sectional study.

Rev Bras Enferm. 2020;73(Suppl 4):e20180996. doi: http://dx.doi.org/10.1590/0034-7167-2018-0996

Corresponding author:

Fernanda Penido Matozinhos E-mail: nandapenido@hotmail.com

EDITOR IN CHIEF: Dulce Aparecida Barbosa ASSOCIATE EDITOR: Margarida Vieira

Submission: 12-02-2019

Approval: $01-04-2020$

\section{ABSTRACT}

Objectives: to investigate the factors associated with the mode of delivery in pregnant women in the city of Belo Horizonte. Methods: cross-sectional study developed with data from the study "Being born in Belo Horizonte: survey on childbirth and birth" carried out in seven maternity hospitals in Belo Horizonte - Minas Gerais. The final sample consisted of 1088 regnant/postpartum women. In this study, to verify the magnitude of the association between the outcome variable and its possible determinants (exposure variables) logistic regression models were constructed to estimate the Odds Ratio. Results: increasing age, the lack of companionship, the hospital's private financing for performing delivery and being a first-time pregnant woman increased the chance of delivery by cesarean section. Final Considerations: the knowledge of factors associated with the prevalence of cesarean sections can support reflections among health professionals about this surgical procedure in certain situations, especially when there are no precise clinical indications. Descriptors: Vaginal Delivery; Cesarean Section; Pregnant Woman; Nursing; Obstetrics.

\section{RESUMO}

Objetivos: investigar os fatores associados à via de nascimento em mulheres gestantes do município de Belo Horizonte. Métodos: estudo transversal desenvolvido com dados da pesquisa "Nascer em Belo Horizonte: Inquérito sobre o parto e nascimento", realizada em sete maternidades de Belo Horizonte - Minas Gerais. A amostra final constitui-se de 1088 mulheres gestantes/ puérperas. Neste estudo, para verificar a magnitude da associação entre a variável desfecho e seus possíveis determinantes (variáveis exposição), foram construídos modelos de regressão logística para estimar a Odds Ratio. Resultados: o aumento da idade, a ausência de um acompanhante, o financiamento privado do hospital para a realização do parto e ser gestante primigesta aumentaram a chance de se ter a via de nascimento cesárea. Considerações Finais: o conhecimento dos fatores associados à prevalência de cesariana pode subsidiar reflexões entre os profissionais de saúde sobre este procedimento cirúrgico em determinadas situações, sobretudo quando não tem indicações clínicas precisas.

Descritores: Parto Normal; Cesárea; Gestante; Enfermagem; Obstetrícia.

\section{RESUMEN}

Objetivos: investigar los factores asociados con la ruta de nacimiento en mujeres embarazadas en la ciudad de Belo Horizonte. Métodos: estudio transversal desarrollado con datos de la investigación "Nacer en Belo Horizonte: Encuesta sobre el parto y el nacimiento", realizada en siete hospitales de maternidad en Belo Horizonte - Minas Gerais. La muestra final consistió en 1088 mujeres embarazadas/postparto. En este estudio, para verificar la magnitud de la asociación entre la variable de resultado y sus posibles determinantes (variables de exposición), se construyeron modelos de regresión logística para estimar el Odds Ratio. Resultados: el aumento de la edad, la ausencia de un acompañante, la financiación privada del hospital para el parto y el hecho de ser una mujer embarazada por primera vez aumentaron las posibilidades de tener una ruta de parto por cesárea. Consideraciones Finales: el conocimiento de los factores asociados con la prevalencia de cesáreas puede apoyar las reflexiones entre los profesionales de la salud sobre este procedimiento quirúrgico en ciertas situaciones, especialmente cuando no hay indicaciones clínicas precisas.

Descriptores: Parto Normal; Cesárea; Mujer Embarazada; Enfermería; Obstetricia. 


\section{INTRODUCTION}

Over the years, labor and delivery assistance in Western societies has undergone major changes. Initially, it was configured as a home event, with pregnant women and midwives ${ }^{(1)}$. This scenario changed gradually in modern times, with the insertion of the medical professional and the hospital context ${ }^{(1)}$.

These changes were associated with the consolidating ways of life and values that favored technologies, economic benefit, the biologicist science ${ }^{(2)}$, and techniques such as cesarean surgery and anesthesia ${ }^{(3)}$.

With transformations of modern society and the hospital context, assistance to labor, delivery and birth was based on a culture in which the biomedical model of assistance is the center of the whole process of giving birth ${ }^{(2)}$. Given this context, the process of giving birth has become ingrained in an interventionist culture and among these interventions, cesarean section has been consolidated as the first choice mode of delivery ${ }^{(4)}$.

Although the cesarean delivery has made births with absolute obstetric indications safer and reduced maternal and neonatal mortality, rates of cesarean sections without real indications are still very high ${ }^{(5)}$. According to the World Health Organization (WHO) ${ }^{(6)}$, absolute indications for a cesarean delivery are cephalopelvic disproportion and total placenta previa; other situations should be assessed individually, especially during labor ${ }^{(6)}$. The frequency of cesarean sections in Brazil has shown an increasing trend since the mid-1990s, reaching 57\% in 2014, with a reduction to $55.5 \%$ in 2015 , and higher prevalence in the private health system compared to the public health system ${ }^{(6)}$.

The risk of complications resulting from the high and unnecessary number of caesarean sections, especially elective cesarean sections, contributes to higher maternal mortality rates ${ }^{(7)}$. Furthermore, according to the $\mathrm{WHO}$, the main causes of maternal death are hemorrhage, abortion and indirect obstetric causes ${ }^{(6)}$. Given the above, in the absence of contraindications, vaginal delivery guarantees benefits and lower risks for the mother and the baby ${ }^{(8)}$.

Women's process of choosing a cesarean delivery is influenced by different individual factors such as lower age, higher education and higher income, previous experience of cesarean section and white color/race ${ }^{(9)}$. Associated with these individual variables, the mode of delivery is also influenced by financing factors from the hospital where the pregnant woman will give birth, mainly in private services, such as: financial reimbursement offered by the Brazilian supplementary health insurance, issues related to infrastructure and qualification of human resources ${ }^{(10-11)}$.

As childbirth is a physiological, natural process and part of women's reproductive rights, they must actively participate in the process of choosing the mode of delivery and other aspects composing the obstetric context. In this perspective, childbirth presupposes that women's informed and conscious choice for each procedure performed on their body is also guided by their physical and psychic time and their choices related to the environment, aiming for the minimum of biomedical interventions and having woman as the center of care ${ }^{(12)}$.

Health professionals involved in childbirth and birth care should avoid the process of medicalization of childbirth, unnecessary interventions, and help women with the choice of their preferred mode of delivery based on recent scientific evidence ${ }^{(13)}$. However, there is a common trend that professionals induce a certain mode of delivery without references to scientific evidence or effective participation of women, meeting the interests of the team and the institution ${ }^{(14)}$.

\section{OBJECTIVES}

To investigate the factors associated with the mode of delivery in pregnant women in the city of Belo Horizonte.

\section{METHODS}

\section{Ethical Aspects}

This study was approved by the Ethics Committee of the Universidade Federal de Minas Gerais and by the Ethics Committees of the maternities involved. Data collection started after obtaining parturient women's signature of the Informed Consent form.

\section{Design, study location and period}

This is a cross-sectional study developed with data from the study "Being born in Belo Horizonte: survey on childbirth and birth", carried out in seven maternities that serve the public health system and in four maternities that serve the supplementary health system of Belo Horizonte - Minas Gerais.

The study "Being born in Belo Horizonte: survey on childbirth and birth" used the same method of sampling, logistics and material resources as the nationwide study entitled "Being born in Brazil: survey on childbirth and birth"(15-16).

\section{Sample}

Regarding inclusion criteria, all women admitted to the selected maternity hospitals for giving birth participated in this study. The final sample included 1088 mothers.

Data collection took place from November 2011 to March 2013 by interviewing the mothers at least six hours after delivery (preestablished time defined as a minimum interval for postpartum rest) and by investigating their medical records.

\section{Study protocol}

The outcome variable of this study was the mode of delivery, being: 0 - Vaginal delivery and 1 - Cesarean delivery.

The variables included in this study referred to sociodemographic characteristics, obstetric, clinical, pregnancy and childbirth history, in addition to the source of hospital funding (public or private).

A variable called intercurrences (clinical or obstetric) during pregnancy or childbirth was also created and would possibly influence in the greater chance of childbirth by cesarean section. The presence of at least one of the following conditions was considered as an intercurrence: pre-existing clinical diseases, hypertensive syndromes, diabetes, gestational diabetes, HIV infection, intrauterine growth restriction (IUGR), oligohydramnios, 
polyhydramnios, alloimmunization, placenta previa, placental abruption, fetal distress, premature labor, severe congenital malformation, two or more previous cesarean sections, failure to induce labor and complications in the evolution of labor ${ }^{(9)}$, in addition to cervical insufficiency, premature rupture of fetal membranes, eclampsia and previous uterine surgeries (myomectomy, micro cesarean section or other body surgeries).

\section{Analysis of results and statistics}

The Statistical Software for Data Science (Stata), version 14.0, was used for data analysis.

The estimates were presented in proportions (\%) with their respective Confidence Intervals ( $95 \% \mathrm{Cl}$ ). For quantitative variables, after asymmetry was verified by the Shapiro-Wilk test, data were presented using median and interquartile range (IQR). To check the magnitude of the association between the outcome variable and its possible determinants (exposure variables), logistic regression models were constructed to estimate the Odds Ratio (OR).

For the multivariate regression model, the backward method was used to construct the model and all variables of interest related to a level of statistical significance below $20 \%$ were included in the bivariate analysis, being removed one by one. To assess the adjustments of the final model, the Hosmer-Lemeshow's model goodness of fit test was used.

\section{RESULTS}

The sample of this study was composed of 1088 women with a median age of 28 years (IQR $=23$ - 33 years), predominance of self-reported mixed race (65.53\%), performing paid work (53.49\%), with secondary education (54.23\%) and in a civil partnership (73.07\%). Regarding obstetric history, the median was eight prenatal consultations (IQR $=7$ - 10), 95.95\% had companionship in the prenatal period, childbirth and immediate postpartum, $81.80 \%$ had no type of clinical or obstetric intervention and $67.56 \%$ had their children in publicly funded hospitals (Table 1).

Table 1 - Sociodemographic and obstetric profile of puerperal women, Belo Horizonte, Minas Gerais, Brazil, 2011-2013

\begin{tabular}{|c|c|c|}
\hline & $n(\%)$ & $95 \% \mathrm{Cl}$ \\
\hline \multicolumn{3}{|l|}{ Sociodemographic } \\
\hline $\mathrm{Age}^{*}$ & $28(23-33)$ & \\
\hline \multicolumn{3}{|l|}{ Skin Color } \\
\hline White & 285(26.19) & $23.66-28.89$ \\
\hline Black & $90(8.27)$ & $6.77-10.06$ \\
\hline Mixed race $* *$ & $713(65.53)$ & $62.65-68.30$ \\
\hline \multicolumn{3}{|l|}{ Paid Work } \\
\hline No & $506(46.51)$ & $43.55-49.48$ \\
\hline Yes & $582(53.49)$ & $50.51-56.44$ \\
\hline \multicolumn{3}{|l|}{ Schooling } \\
\hline None and Elementary School & $311(28.58)$ & $25.97-31.34$ \\
\hline High School & $590(54.23)$ & $51.25-57.17$ \\
\hline University education & $187(17.19)$ & $15.05-19.55$ \\
\hline \multicolumn{3}{|l|}{ Marital Status } \\
\hline With partner & 795(73.07) & $70.34-75.62$ \\
\hline Without partner & 293(26.93) & $24.37-29.65$ \\
\hline \multicolumn{3}{|l|}{ Obstetric } \\
\hline Number of prenatal consultations* & $8(7-10)$ & \\
\hline \multicolumn{3}{|l|}{ Place of prenatal consultations } \\
\hline Public & 634(58.70) & $55.73-61.61$ \\
\hline Private & $387(35.83)$ & $33.02-38.74$ \\
\hline Both & $59(5.46)$ & $4.25-6.99$ \\
\hline \multicolumn{3}{|l|}{ Primigravida } \\
\hline No & $603(55.42)$ & $52.44-58.35$ \\
\hline Yes & $485(44.58)$ & $41.64-47.55$ \\
\hline \multicolumn{3}{|c|}{ Companionship in prenatal period, childbirth and immediate postpartum } \\
\hline No & $44(4.04)$ & $3.02-5.39$ \\
\hline Yes & 1044(95.95) & $94.60-96.97$ \\
\hline \multicolumn{3}{|l|}{ Clinical and obstetric complications } \\
\hline No & 198(18.20) & $16.01-20.60$ \\
\hline Yes & $890(81.80)$ & $79.39-83.98$ \\
\hline \multicolumn{3}{|l|}{ Funding of the birth hospital } \\
\hline Private & $353(32.44)$ & $29.72-35.29$ \\
\hline Public & $735(67.56)$ & $64.70-70.27$ \\
\hline
\end{tabular}

Table 2 - Factors associated with the mode of delivery, Belo Horizonte, Minas Gerais, Brazil, 2011-2013

\begin{tabular}{|c|c|c|c|c|}
\hline & \multicolumn{2}{|c|}{ Mode of delivery } & \multicolumn{2}{|c|}{ Crude model* } \\
\hline & $\begin{array}{c}\text { Vaginal } \\
\text { n(\%) }\end{array}$ & $\begin{array}{c}\text { Cesarean } \\
\text { n(\%) }\end{array}$ & $\begin{array}{l}\text { OR } \\
(95 \%)\end{array}$ & $\begin{array}{c}p \\
\text { value }\end{array}$ \\
\hline \multicolumn{5}{|l|}{ Sociodemographic } \\
\hline Age $^{*}$ & $26(21-31)$ & $31(25-34)$ & $1.09(1.07-1.11)$ & $<0.001$ \\
\hline Schooling & & & & $<0.001$ \\
\hline Elementary School & 205(65.92) & $106(34.08)$ & 1 & \\
\hline High School & $340(57.63)$ & $250(42.37)$ & $1.42(1.07-1.89)$ & \\
\hline University Education & $55(29.41)$ & $132(70.59)$ & $4.64(3.15-6.91)$ & \\
\hline Skin Color & & & & $<0.001$ \\
\hline Asian* & $420(58.91)$ & 293(41.09) & 1 & \\
\hline White & $128(44.91)$ & $157(55.09)$ & $1.75(1.33-2.33)$ & \\
\hline Black & $52(57.78)$ & $38(42.22)$ & $1.04(0.66-1.62)$ & \\
\hline Marital Status & & & & $<0.001$ \\
\hline With partner & $404(50.82)$ & $391(49.18)$ & 1 & \\
\hline Without partner & $196(66.89)$ & $97(33.11)$ & $0.51(0.38-0.67)$ & \\
\hline Paid Work & & & & $<0.001$ \\
\hline No & $316(62.45)$ & 190(37.55) & 1 & \\
\hline Yes & $284(48.80)$ & $298(51.20)$ & $1.74(1.37-2.22)$ & \\
\hline \multicolumn{5}{|l|}{ Obstetric } \\
\hline Number of prenatal consultations & $8(6-9)$ & $9(7-10)$ & $1.19(1.13-1.26)$ & $<0.001$ \\
\hline Place of prenatal consultations & & & & $<0.001$ \\
\hline Public & $443(69.87)$ & 191(30.13) & 1 & \\
\hline Private & $123(31.78)$ & $264(68.22)$ & $4.97(3.78-6.54)$ & \\
\hline Both & $29(49.15)$ & $30(50.85)$ & $2.39(1.40-4.10)$ & \\
\hline Primigravida & & & & 0.502 \\
\hline No & $338(56.05)$ & $265(43.95)$ & 1 & \\
\hline Yes & $262(54.02)$ & $223(45.98)$ & $1.08(0.85-1.38)$ & \\
\hline
\end{tabular}




\begin{tabular}{|c|c|c|c|c|}
\hline & \multicolumn{2}{|c|}{ Mode of delivery } & \multicolumn{2}{|c|}{ Crude model* } \\
\hline & $\begin{array}{l}\text { Vaginal } \\
\text { n(\%) }\end{array}$ & $\begin{array}{c}\text { Cesarean } \\
\text { n(\%) }\end{array}$ & $\begin{array}{c}\text { OR } \\
(95 \%)\end{array}$ & $\begin{array}{c}p \\
\text { value }\end{array}$ \\
\hline $\begin{array}{l}\text { Companionship in prenatal period, } \\
\text { childbirth and immediate postpartum }\end{array}$ & & & & 0.188 \\
\hline Yes & $580(55.56)$ & $464(44.44)$ & 1 & \\
\hline No & $20(45.45)$ & $24(54.55)$ & $1.49(0.81-2.74)$ & \\
\hline Clinical and obstetric complications & & & & $<0.001$ \\
\hline No & $163(82.32)$ & $35(17.68)$ & 1 & \\
\hline Yes & $437(49.10)$ & $453(50.90)$ & $4.82(3.27-7.11)$ & \\
\hline Funding of the birth hospital & & & & $<0.001$ \\
\hline Public & $511(69.52)$ & $224(30.48)$ & 1 & \\
\hline Private & $89(25.21)$ & $264(74.79)$ & $6.76(5.07-9.01)$ & \\
\hline
\end{tabular}

Over the past few years, a relationship has been observed between the increase in the average age of pregnant women and the increase in the number of cesareans ${ }^{(17)}$. The association between mode of delivery and maternal age has been observed in other studies. More advanced ages were related to complications that reflect the choice of delivery mode ${ }^{(18-19)}$. In this study, this association remained significant even after adjustments for complications and other confounders, reinforcing the

Table 3 - Adjusted final model of factors associated with the mode of delivery, Belo Horizonte, Minas Gerais, Brazil, 2011-2013

\begin{tabular}{|c|c|c|}
\hline Variable & $\begin{array}{c}\text { Adjusted } \\
\text { Model* } \\
\text { OR(95\%) }\end{array}$ & $\begin{array}{c}p \\
\text { value }\end{array}$ \\
\hline Age & $1.07(1.04-1.10)$ & $<0.001$ \\
\hline Primigravida & & 0.025 \\
\hline No & 1 & \\
\hline Yes & $1.43(1.04-1.96)$ & \\
\hline $\begin{array}{l}\text { Companionship in prenatal period, delivery } \\
\text { and immediate postpartum }\end{array}$ & & 0.048 \\
\hline Yes & 1 & \\
\hline No & $1.95(1.01-3.80)$ & \\
\hline Funding of the birth hospital & & $<0.001$ \\
\hline Public & 1 & \\
\hline Private & $3.98(2.44-6.48)$ & \\
\hline
\end{tabular}

Regarding the outcome variable, $55.15 \%$ of puerperal women had a vaginal delivery. In the bivariate analysis, variables associated with the mode of delivery were age, schooling, skin color, marital status, performing some type of paid work, number of prenatal consultations, place of prenatal consultations, clinical and obstetric complications and hospital funding (Table 2).

Table 3 shows that after adjustments, the one-year increase of a pregnant woman's age increased, on average, 1.07 (95\% Cl 1.04 - 1.10) times her chance of giving birth by cesarean section. In addition, being a first-time pregnant woman increased, on average, 1.43 (95\% Cl 1.04 - 1.96) times the chance of undergoing a cesarean section compared to multiparous women. Women without a companionship in the prenatal period, childbirth and immediate postpartum period had, on average, a 1.95 (95\% Cl $1.01-3.80)$ times higher chance of having their children by cesarean section compared to pregnant women with a companionship. Pregnant women who had their babies in a private hospital had, on average, a 3.98 (95\% Cl 2.44 - 6.48) times higher chance of having a cesarean delivery compared to those who gave birth in public hospitals.

\section{DISCUSSION}

This study demonstrated that older women, primigravida women, who delivered their children in a privately funded hospital and did not have a companionship had higher chances of experiencing a cesarean section. independent relationship with generational factors ${ }^{(20)}$. Although in recent years the recommendation has been that women choose the mode of delivery, this option still happens based on professional information, which allows fewer choices, induces decisions and hurts women's autonomy ${ }^{(20)}$.

The socially constructed character of childbirth contributes to its different meanings in a society, varying according to generations, races, ethnicities and social classes. The factors of generation and motherhood in relation to the increasing age have been little studied ${ }^{(21)}$.

In pregnancy experiences, social aspects are translated by ingrained cultures, considered natural ${ }^{(22)}$. Thus, the reduction in fertility that occurs with increasing age also leads to a social understanding of worse health status, since in Western society, the perception of women's health is often related to the fertility factor. The indication of cesarean section, which is often related to social perceptions and not scientific evidence, can be based only on technical (biological) issues for poor health conditions, as it is assumed to be the condition of older women.

In this study, among first-time pregnant women, there was a higher chance of having children by cesarean section. In primigravida, a cesarean delivery must also be performed with precise indication $^{(23)}$. It is known that the evolution of labor tends to take longer among primiparous women ${ }^{(24)}$ and culminates in a higher number of unnecessary interventions ${ }^{(25)}$, including cesarean sections. The American College of Obstetricians and Gynecologists ${ }^{(26)}$ guides the reduction of the number of caesarean deliveries in primiparous women, as this choice may be decisive in future pregnancies ${ }^{(20,26)}$. In this case, differently from older women, who are perceived as having a fragile health, the cesarean delivery route is used for primiparous women as an option related to the lack of experience, capable of responding to a cultural demand. In this case, the experience would be an uncontrollable one, which is learned in a way that involves suffering and also requires authority from women, authority to experience something that has been controlled by doctors since the $18^{\text {th }}$ century ${ }^{(27)}$.

This study also showed that not having a companionship increases women's chance of undergoing a cesarean section. Having a companionship in labor and postpartum is a parturient woman's right supported by Brazilian law 11,108 of April 7,2005. The presence of a companionship in labor is proven to be related to emotional benefits. Provides calm, tranquility and security. This undoubtedly contributes to a reduction in the rate of cesarean section, a decrease in the use of oxytocin, time of labor and use of drugs for pain relief ${ }^{(1)}$. 
Finally, this study showed that cesarean rates are related to the funding of the hospital, that is, women in the private system are more likely to have surgical delivery compared to women in public hospitals, with a significant association after adjustments. This relationship has been observed in other studies ${ }^{(4,28)}$, thereby suggesting the occurrence of a large number of cesarean sections without indication, mainly, in the private sector.

The practice of cesarean delivery due to maternal decision is not usual in Brazilian public hospitals ${ }^{(29)}$. Especially in university maternity wards, care protocols are well defined and routinely used, thereby avoiding unnecessary cesarean deliveries. In these environments, concerns about the humanization of care emerge as part of a multidisciplinary team in which evidence-based practice is valued.

In recent years, cesarean section has ceased to be an exclusive method for improving perinatal results, often becoming a consumer commodity, more common in women with greater purchasing power and high schooling ${ }^{(26)}$. Therefore, socioeconomic issues can be related to female protagonism in the choice for the mode of delivery, issues of access and equity in health services ${ }^{(30)}$. In this direction, choosing a cesarean delivery can also be related to social status and the fact that women can choose the day and time the baby will be born and the perspective of avoiding the pain of vaginal delivery ${ }^{(28)}$.

Obstetric interventions, especially cesarean sections, showed great disparity between the risk groups and a still very high rate in the usual risk group composed of pregnant women with no real clinical or obstetric indication for cesarean section ${ }^{(31)}$. The risks outweigh the benefits and therefore, caesarean deliveries should be performed with caution and safety ${ }^{(5)}$. Possible complications are associated with postpartum infection, admission to the intensive care unit, maternal death, among others.

In this sense, the factors associated with the mode of delivery found in this study lead us to the discussion about "contracted maternity" and "experience maternity" that helps to problematize choices in the obstetric context and can result in very different perspectives ${ }^{(12)}$. On the one hand, there are choices related to the perspective of contracted maternity, in which although women decide, they end up adhering to practices that distance them from their own bodies and selfless desires in the face of institutional control $^{(12)}$. On the other hand, there are more referenced choices from the perspective of experience, in which there is a possibility to create, experiment and even transcend the hegemonic institutional models ${ }^{(12)}$.
The decision of mode of delivery should often be analyzed by more than one health professional and made together with the pregnant woman, respecting their autonomy. The training of some professionals can guide them to the understanding of cesarean delivery as a practical and safe procedure, in addition to the surgery being recognized by several parturient women as a pain reduction mechanism, disregarding perinatal risks ${ }^{(31)}$.

\section{Study limitations}

Firstly, the fact that interviews were conducted after delivery may have altered the report of some women. In addition, some data regarding conditions that could be associated with the indication for cesarean delivery were absent, even though the availability in the database allowed for inferences, even if indirect. Finally, the need to replicate these analyzes in a representative sample for the city of Belo Horizonte is reinforced.

\section{Contributions to Nursing}

The present study contributes to the advancement in the discussion about factors associated with the mode of delivery in pregnant women. By knowing these factors, multidisciplinary team members can avoid unnecessary interventions in childbirth and birth care. Such professionals must be based on recent scientific evidence and have an efficient clinical judgment in order to prioritize essential aspects in this context, such as the woman's desire and her physiological conditions.

\section{CONCLUSIONS}

The knowledge of factors associated with the prevalence of cesarean deliveries can support reflections among health professionals about this surgical procedure in certain situations, especially when there are no precise clinical indications. A cesarean delivery should be performed when a benefit is identified that neutralizes the costs and risks added to this mode of delivery.

\section{FUNDING}

National Council for Scientific and Technological Development (Portuguese acronym: CNPq). Process number: 402369 / 2010-6.

Thanks for the support of the Núcleo de Estudo e Pesquisa em Vacinação da Escola de Enfermagem of the Universidade Federal de Minas Gerais (Portuguese acronym: NUPESV).

\section{REFERENCES}

1. Marcos J, Santos J, Wiliane M, Cunha N, Mendes RB, Souza L, et al. Pregnant woman's position during vaginal delivery: discrepancies between medical and nursing practices. Rev Bras Pesq Saúde. 2017;19(4):58-64. doi: 10.21722/rbps.v19i4.19804

2. Davis-Floyd R. Ways of knowing about birth: Mothers, midwives, medicine, and birth activism. Waveland Press; 2017.

3. Vendrúscolo CT, Kruel CS. A história do parto: do domicílio ao hospital; das parteiras ao médico; de sujeito a objeto. Discip Sci Ciênc Hum [Internet]. 2015[cited 2019 Oct 16];16(1):95-107. Available from: http://www.periodicos.unifra.br/index.php/disciplinarumCH/article/ view/1842/1731

4. Kottwitz F, Gouveia HG, Gonçalves AC. Route of birth delivery preferred by mothers and their motivations. Esc Anna Nery. 2017;22(1):1-8. doi: 10.1590/2177-9465-ean-2017-0013 
5. Mascarello, KC, Horta BL, Silveira M. Maternal complications and cesarean section with-out indication: systematic review and meta-analysis. Rev Saude Publica. 2017;5151:1-12. doi: 10.11606/s1518-8787.2017051000389

6. World Health Organization (WHO). Declaração da OMS sobre Taxas de Cesáreas. World Health Organ [Internet]. 2015[cited 2019 Oct 16];1-8. Available from: http://www.who.int/about/ licensing/copyright_form/en/index.html

7. Victora CG, Aquino EM, Carmo Leal M, Monteiro CA, Barros FC, Szwarcwald CL. Mater-nal and child health in Brazil: progress and challenges. Lancet. 2011;377(9780):1863-76. doi: 10.1016/S0140-6736(11)60138-4

8. Marcolin AC. Until when will Brazil be known as the country of cesarean section? Rev Bras Ginecol Ob. 2014;36(7):283-9. doi: 10.1590/ SO100-720320140005087

9. Domingues RMSM, Dias MAB, Nakamura-Pereira M, Torres JA, D'Orsi E, Pereira APE, et al. Process of decision-making regarding the mode of birth in Brazil: from the initial pref-erence of women to the final mode of birth. Cad Saude Publica. 2014;30(suppl 1):S101-16. doi: 10.1590/0102-311X00105113

10. Ramires de Jesus G, Ramires de Jesus N, Peixoto-Filho FM, Lobato G. Caesarean rates in Brazil: what is involved? BJOG. 2015;122(5):606-9. doi: $10.1111 / 1471-0528.13119$

11. Bettes BA, Coleman VH, Zinberg S, Spong CY, Portnoy B, DeVoto E, et al. Cesarean de-livery on maternal request: obstetrician-gynecologists' knowledge, perception, and practice patterns. Obstet Gynecol. 2007;109(1):57-66. doi: 10.1097/01.AOG.0000249608.11864.b6

12. Carneiro RG. Cenas de parto e políticas do corpo. SciELO-Editora FIOCRUZ; 2015.

13. Possati AB, Prates LA, Cremonese L, Scarton J, Alves CN, Ressel LB. Humanization of childbirth: meanings and perceptions of nurses. EsC Anna Nery. 2017;21(4):1-6. doi: 10.1590/2177-9465-ean-2016-0366

14. Nascimento RRP, Arantes SL, Souza EDC, Contrera L, Sales APA. Choice of type of de-livery: factors reported by puerperal woman. Rev Gaúcha Enferm. 2015;36(spe):119-26. doi: 10.1590/1983-1447.2015.esp.56496

15. Vasconcellos MTL, Silva PLN, Pereira APE, Schilithz AOC, Souza-Jr PRB, Szwarcwald CL. Sampling design for the Birth in Brazil: National Survey into Labor and Birth. Cad Saúde Pública. 2014;30(Supl.):S49-58. doi: 10.1590/0102-311X00176013

16. Leal MC, Silva AAM, Dias MAB, Gama SGN, Rattner D, Moreira ME, et al. Birth in Brazil: national survey into labour and birth. Reprod Health. 2012;9(1):15. doi: 10.1186/1742-4755-9-15

17. Herstad L, Klungsøyr K, Skjærven R, Tanbo T, Forsén L, Åbyholm T, et al. Elective cesar-ean section or not? maternal age and risk of adverse outcomes at term: a population-based registry study of low-risk primiparous women. BMC Pregnancy Childbirth. 2016;16(1):1-11. doi: 10.1186/s12884-016-1028-3

18. Richards MK, Flanagan MR, Littman AJ, Burke AK, Callegari LS. Primary cesarean section and adverse delivery outcomes among women of very advanced maternal age. J Perinatol. 2016;36(4):272-7. doi: 10.1038/jp.2015.204

19. Copelli FHS, Rocha L, Zampieri MFM de FM, Gregório VRP, Custódio ZAO. Determinants of women's preference for cesarean section. Texto Contexto Enferm. 2015;24(2):336-43.doi: 10.1590/0104-07072015000430014

20. Weidle WG, Medeiros CRG, Grave MTQ, Dal Bosco SM. Choice of delivery method by the woman: autonomy or induction? Cad Saúde Coletiva. 2014;22(1):46-53. doi: 10.1590/1414-462X201400010008

21. Robles AF. Regulation of the body and parentality during the prenatal period in working-class young women. Rev Ciências Sociais. 2015;15(2):190-213. doi: 10.15448/1984-7289.2015.2.17985

22. Paim HHS. Marcas no corpo: gravidez e maternidade em grupos populares. Doença, sofri-mento, perturbação. Perspect etnográficas. 1998.

23. Saraiva JM, Gouveia HG, Gonçalves AC. Factors associated with cesarean sections in a high complexity university hospital in southern Brazil. Rev Gaúcha Enferm. 2017;38(3):e69141. doi: 10.1590/1983-1447.2017.03.69141

24. Pádua KS, Osis MJD, Faúndes A, Barbosa AH, Moraes Filho OB. Factors associated with cesarean sections in Brazilian. Rev Saude Publica. 2010;44(1):70-9. doi: 10.1590/S0034-89102010000100008

25. Monteschio LVC, Sgobero JCGS, Oliveira RR, Serafim D, Mathias TAF. Prevalence of medicalization of labor and delivery in the public health network. Ciên Cuid Saúde. 2016;15(4):591. doi: 10.4025/cienccuidsaude.v15i4.33420

26. Caughey AB, Cahill AG, Guise JM, Rouse DJ. Safe prevention of the primary cesarean delivery. Am J Obstet Gynecol. 2014;210(3):179-93. doi: 10.1016/j.ajog.2014.01.026

27. Carneiro RG. Dizer sim à experiência. Cad Espaço Fem. 2009;22(2).

28. Guimarães RM, Silva RLPD, Dutra VGP, Andrade PG, Pereira ACR, Jomar RT et al . Fac-tors associated to the type of childbirth in public and private hospitals in Brazil. Rev Bras Saude Mater Infant. 2017;17(3):571-80. doi: 10.1590/1806-93042017000300009

29. Faisal-Cury A, Menezes PR, Quayle J, Santiago K, Matijasevich A. The relationship be-tween indicators of socioeconomic status and cesarean section in public hospitals. Rev Saude Publica. 2017;51:1-11. doi: 10.1590/s1518-8787.2017051006134

30. Silva LM, Silva RA, da Silva AAM, Bettiol H, Barbieri MA. Racial inequalities and perina-tal health in the southeast region of Brazil. Brazilian J Med Biol Res. 2007;40(9):1187-94. doi: 10.1590/S0100-879X2006005000144

31. Riscado LC, Jannotti CB, Helena R, Barbosa S. Deciding the Route of Delivery in Brazil : Themes and Trends in Public Health Production. Texto Contexto Enferm. 2016;25(1):1-10. doi: 10.1590/0104-0707201600003570014 